\title{
Assessing downstream flood impacts due to a potential GLOF from Imja Tsho in Nepal
}

\author{
M. A. Somos-Valenzuela ${ }^{1}$, D. C. McKinney ${ }^{1}$, A. C. Byers ${ }^{2}$, D. R. Rounce ${ }^{1}$, C. Portocarrero ${ }^{3}$, and D. Lamsal ${ }^{4}$ \\ ${ }^{1}$ Center for Research in Water Resources, University of Texas at Austin, Austin, Texas, USA \\ ${ }^{2}$ The Mountain Institute, Washington DC, USA \\ ${ }^{3}$ Independent Consultant, Huaraz, Peru \\ ${ }^{4}$ Graduate School of Environmental Studies, Nagoya University, Japan \\ Correspondence to: D. C. McKinney (daene@aol.com)
}

Received: 24 September 2014 - Published in Hydrol. Earth Syst. Sci. Discuss.: 25 November 2014

Revised: 26 February 2015 - Accepted: 27 February 2015 - Published: 13 March 2015

\begin{abstract}
Glacial-dominated areas pose unique challenges to downstream communities in adapting to recent and continuing global climate change, including increased threats of glacial lake outburst floods (GLOFs) that can increase risk due to flooding of downstream communities and cause substantial impacts on regional social, environmental and economic systems. The Imja glacial lake (or Imja Tsho) in Nepal, which has the potential to generate a GLOF, was studied using a two-dimensional debris-flow inundation model in order to evaluate the effectiveness of proposed measures to reduce possible flooding impacts to downstream communities by lowering the lake level. The results indicate that only minor flood impact reduction is achieved in the downstream community of Dingboche with modest $(\sim 3 \mathrm{~m})$ lake lowering. Lowering the lake by $10 \mathrm{~m}$ shows a significant reduction in inundated area. However, lowering the lake by $20 \mathrm{~m}$ almost eliminates all flood impact at Dingboche. Further downstream at Phakding, the impact of the GLOF is significant and similar reductions in inundation are likely as a result of lake lowering.
\end{abstract}

\section{Introduction}

Recent worldwide retreat of glaciers (WGMS, 2013) has been very evident in the Mt. Everest region of Nepal where glacial lakes continue to form and grow, significantly increasing the risk of glacial lake outburst floods (GLOFs) (Bajracharya et al., 2007a; ICIMOD, 2011; Ives et al., 2010; Shrestha and Aryal, 2011). Many of these lakes are consid- ered potentially dangerous (Bajracharya et al., 2007a; Bolch et al., 2008; Watanabe et al., 2009; ICIMOD, 2011); therefore, risk and vulnerability assessments of communities and assets located downstream of glacial lakes in this region have become necessary. Remedial actions have been taken to reduce the risk of GLOFs, in one case at Tsho Rolpa lake (Rana et al., 2000) and another under design at Imja Tsho (or Imja Lake) (UNDP, 2013). In the region near Imja Tsho (Fig. 1), there have been 2 GLOFs in recent decades (Nare in 1977 and Dig Tsho in 1985) resulting in significant damage to farms, villages, trails and some loss of life (Buchroithner et al., 1982; Ives, 1986; Vuichard and Zimmermann, 1986).

Imja Tsho, located in the Khumbu region $\left(27.9^{\circ} \mathrm{N}\right.$, $86.9^{\circ} \mathrm{E}$; Fig. 1), is a supraglacial lake formed on top of Imja glacier, and it is bounded on the east by the Lhotse Shar and Imja glaciers, on the north and south by lateral moraines, and to the west by a $700 \mathrm{~m}$ wide by $700 \mathrm{~m}$ long ice-cored terminal moraine complex that has an outlet that drains the lake feeding into the Imja Khola (or Imja River) (Watanabe et al., 2009; Somos-Valenzuela et al., 2013). The lake, which did not exist in 1960, has experienced rapid growth in area and volume; by 2002 it had a volume of $35.8 \pm 0.7$ million $\mathrm{m}^{3}$ (Sakai et al., 2007), and by 2012 the volume had increased to $61.7 \pm 3.7$ million $\mathrm{m}^{3}$ (Somos-Valenzuela et al., 2014). The western, down-valley expansion has stabilized in recent years, while the eastern expansion continues unabated (Watanabe et al., 2009), mostly through calving from the glacier terminus. Avalanche debris falling from surrounding high mountains and hanging ice is prevented from entering the lake by the high lateral moraines, which are separated 


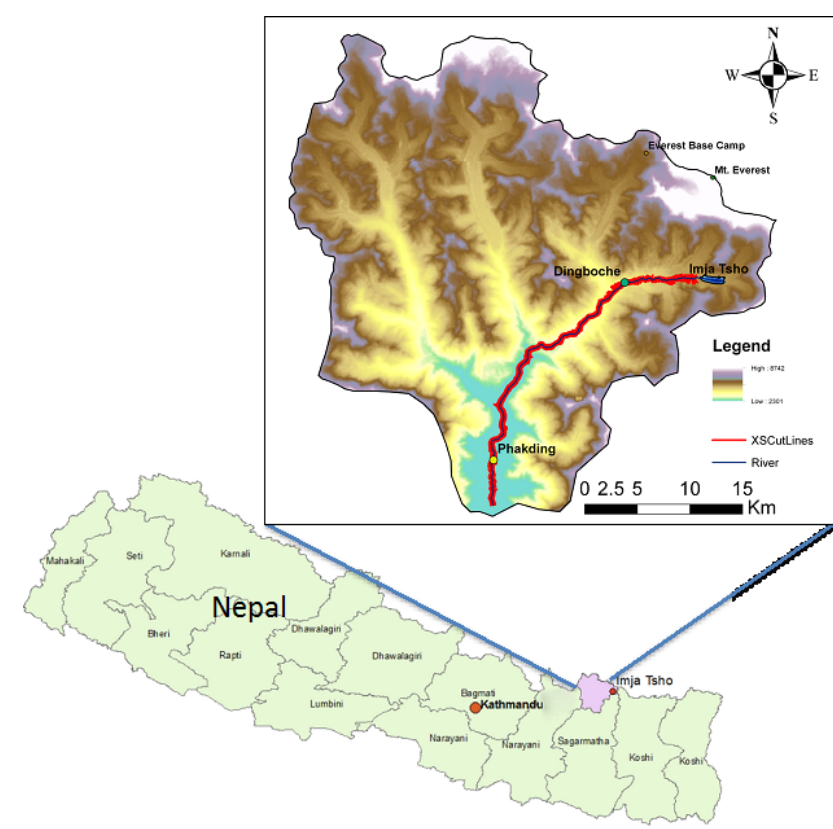

Figure 1. Location of Imja Tsho in the Khumbu region of Nepal.

from the surrounding mountains by several tens of meters (Hambrey et al., 2008). The bottom of the lake has continued to lower as the ice of the glacier beneath the lake melts (Watanabe et al., 1995; Fujita et al., 2009; Somos-Valenzuela et al., 2014).

The characterization of the risk of Imja Tsho is somewhat controversial, with some researchers declaring it to be relatively dangerous (Hammond, 1988; Kattelmann, 2003; Ives et al., 2010), and others concluding that it may be stable (Fujita et al., 2009; Watanabe et al., 2009; ICIMOD, 2011). ICIMOD (2011) identified Imja Tsho as one of six highpriority glacial lakes in Nepal that require detailed investigation, while other studies have stated that Imja Tsho is safe (Fujita et al., 2013) or very low risk (Hambrey et al., 2008). These conflicting classifications are confusing and can be misleading to the general public and communities downstream, who are the stakeholders these studies are meant to assist. Imja Tsho is among six glacial lakes identified in the Nepal National Adaptation Plan of Action (NAPA) as having at the most immediate risk of bursting (MoE, 2010). The United Nations Development Program (UNDP) is implementing the Community Based Flood and Glacial Lake Outburst Risk Reduction Project in an effort to reduce the possible risk to downstream communities posed by the lake. According to the UNDP project strategy (UNDP, 2013), the "GLOF risks arising from Imja Tsho will be significantly reduced by reducing the lake volume through an artificial controlled drainage system combined with a community-based early warning system." They recommend lowering the lake level by at least $3 \mathrm{~m}$ to achieve this risk reduction.

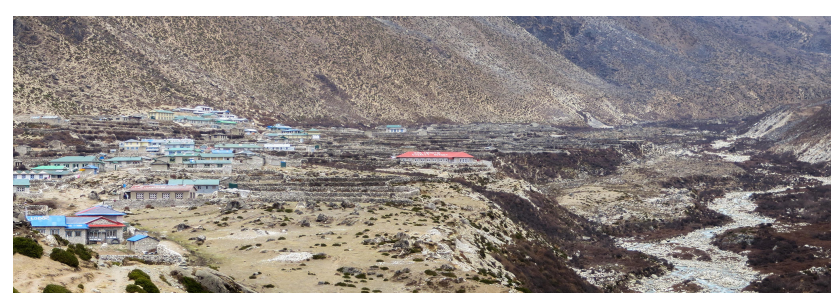

Figure 2. The village of Dingboche on the Imja Khola showing the river (right) and the relative height from the river course to the arable land and houses (about $22 \mathrm{~m}$ ).

Dingboche is probably the most risk prone area from a potential Imja GLOF. The villages of Chukkung $(\sim 4 \mathrm{~km})$ and Dingboche $(\sim 8 \mathrm{~km})$ are the two nearest settlements from the lake. The former is located relatively off the Imja Khola (stream), so at less risk, whereas the latter is the largest settlement along the stream and it has extensive agricultural lands and buildings within 10-20 m elevation from the stream that will be flooded in the event of a GLOF unless flood prevention measures are taken. Two villages in the path of a potential GLOF from Imja Tsho have been the focus of the work reported here: Dingboche $\left(27^{\circ} 53.563^{\prime} \mathrm{N}, 86^{\circ} 50.092^{\prime} \mathrm{E}\right.$; $4410 \mathrm{~m})$ about $8 \mathrm{~km}$ downstream from the lake and Phakding $\left(27^{\circ} 44.624^{\prime} \mathrm{N}, 86^{\circ} 42.767^{\prime} \mathrm{E} ; 2569 \mathrm{~m}\right)$ about $33 \mathrm{~km}$ below Imja Tsho. Dingboche is a village of about 200 residents with an economy that depends on local agriculture and trekking and climbing tourism. Figure 2 shows the Imja Khola and the relative height from the river course to the arable land and houses (about $22 \mathrm{~m}$ above the river). About $34 \mathrm{~km}$ downstream of the lake outlet are low-lying portions of the village Phakding, which is a village of about 1500 residents with an economy that depends on local agriculture and trekking tourism. Most of the village is quite high above the river and is not at risk of damage from a GLOF. However, several farms and lodges are quite close to the river. Figure 3 shows the bridge crossing the Dudh Koshi and the relative height from the river course to the Star Lion lodge (about $13 \mathrm{~m}$ above the river). Lukla, a gateway to the Everest trekking area, can be excluded from consideration here because of its high location from the current riverbed; therefore, the discussion on the section between the lake and Phakding is appropriate.

In this paper we present a new, two-dimensional debrisflow model for predicting the potential GLOF hazard from Imja Tsho in terms of inundation depth in downstream communities and present a measure of uncertainty in the GLOF inundation predictions. We analyze four scenarios: current lake conditions, and three risk mitigation scenarios with the lake water level lowered 3,10 or $20 \mathrm{~m}$ below the current level. Finally, we discuss possible methods for lowering the lake water level to reduce the GLOF hazard. To the authors' knowledge, this is the first attempt to quantify the impact 


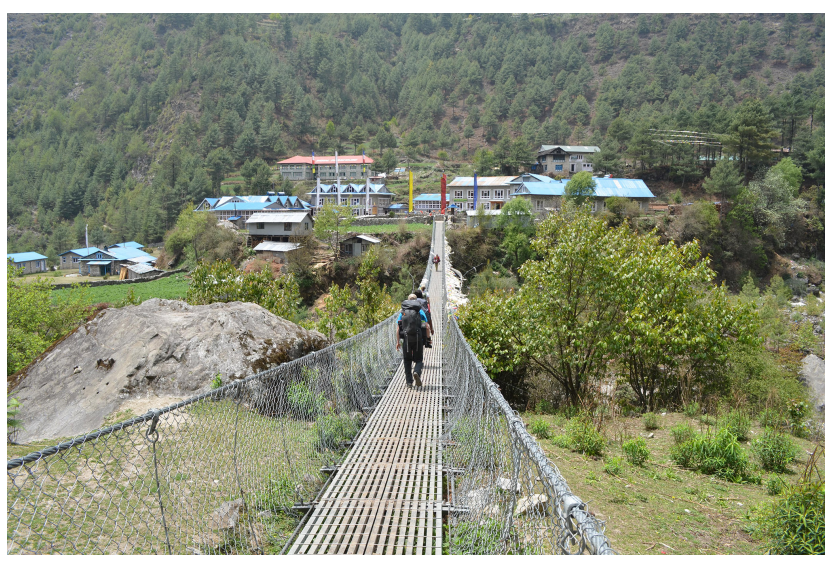

Figure 3. Bridge across the Dudh Koshi at the Star Lion Resort near the village of Phakding showing the bridge and the relative height from the river course to the arable land and houses (about 10 to $13 \mathrm{~m})$.

that various flood control alternatives would have on potential GLOF damage in downstream villages.

\section{Methodology}

\subsection{Data}

To model the propagation of a GLOF from Imja Tsho to the downstream community of Dingboche, we used two digital elevation models (DEMs) for the Imja Tsho GLOF model: (1) a $5 \mathrm{~m} \times 5 \mathrm{~m}$ grid cell DEM of the Imja-Lhotse Shar glacier and the moraine surrounding the lake generated from a 2006 Advanced Land Observing Satellite (ALOS) imagery (Lamsal et al., 2011), and (2) a DEM extending from the lake to just below Dingboche derived using the method of Lamsal et al. (2011). These DEMs provide adequate resolution and terrain data for flooding and inundation modeling; however, they cover only $11 \mathrm{~km}$ of the river basin downstream from the lake. Expanded $5 \mathrm{~m} \times 5 \mathrm{~m}$ DEM coverage downstream of Dingboche could be produced, but ALOS imagery was not available for this work. Instead, we used a lower resolution DEM for the region downstream of Dingboche to just below the village of Phakding. Initially a $30 \mathrm{~m} \times 30 \mathrm{~m}$ resolution DEM was produced from Advanced Space borne Thermal Emission and Reflection Radiometer (ASTER L1) data (Tachikawa, 2011). However, ASTER L1 data has too many unrealistic features, such as many ponds between Imja Tsho and Phakding, that do not exist according to our field observations. Therefore, we decided to use the DEM created from $40 \mathrm{~m}$ interval contour topographic maps produced by Bajracharya et al. (2007b). The modeled portion of the river has a length of $38.5 \mathrm{~km}$ from the lake outlet to a point $5 \mathrm{~km}$ downstream of the village of Phakding.

Roughness coefficients for eight categories of land cover in the basin were assigned using land cover maps derived from 2006 ASTER imagery for the Sagarmatha National park (Bajracharya and Uddin, 2010). These values agreed well with those that Cenderelli and Wohl (2001) calculated for the Imja Khola ( 0.15 and 0.30 for the riverbed and floodplain, respectively), and values that the FLO-2D manual (FLO-2D, 2012) recommends for the types of land cover found in the basin.

Somos-Valenzuela et al. (2014) conducted a bathymetric survey of Imja Tsho in 2012 and estimated the lake volume was $61.7 \pm 3.7$ million $\mathrm{m}^{3}$ and that $34.1 \pm 1.08$ million $\mathrm{m}^{3}$ of water could drain from the lake if the lake surface elevation decreases $35 \mathrm{~m}$ from $5010 \mathrm{~m}$ to $4975 \mathrm{~m}$ (the elevation of the valley floor below the lake). For the Imja Tsho GLOF model, the lake bathymetry was combined with the DEM of the surrounding moraines and the glacier and used as input to the moraine dam breach model described below.

\subsection{Moraine dam breach model}

In order for a GLOF to occur from Imja Tsho, a triggering event is necessary. Such triggers may include slow melting of the ice core within the damming moraine, seepage and piping through the dam and earthquakes (Kattelmann and Watanabe, 1998; Somos-Valenzuela et al., 2013). Other factors that may trigger a GLOF from Imja Tsho include excessive rain and potential blockage of the outlet that may be produced by the ice that has calved at the glacier terminus.

We observed seepage from the base of the southern portion of the damming moraine during five visits to the lake between 2011 and 2014. In September 2013 the seepage was measured using a tape measure and porTable velocity meter (Global Water Flow Probe FP111 turboprop positive displacement sensor with a range of $0.1-6.1 \mathrm{~m} \mathrm{~s}^{-1}$ and an accuracy of $0.03048 \mathrm{~m} \mathrm{~s}^{-1}$ ). At the seepage outlet, two sets of measurements were taken and an average flow of $0.005 \mathrm{~m}^{3} \mathrm{~s}^{-1}$ was calculated. In addition, three sets of flow measurements were made at the Imja Tsho outlet (bridge over the Imja Khola) and an average flow of $2.2 \mathrm{~m}^{3} \mathrm{~s}^{-1}$ was calculated.

To model a potential moraine breach initiating a GLOF from Imja Tsho, we use a combination of moraine breach analysis tools. First, the shape, final size and failure time of the breach are estimated from empirical equations. Failure time is the time needed for complete development of the breach from the initial breakthrough to the end of lateral enlargement (Froehlich, 2008). Second, these parameters are used in a Hydrologic Engineering Center - River Analysis System (HEC-RAS) dam breach model (USACE, 2010) to simulate the breach hydrograph, which is then used as input to a 2-D downstream inundation model.

There are a number of empirical dam breach equations in the literature (Wahl, 2010; Westoby et al., 2014). However, the equations developed by Froehlich (1995) were selected for use here because Wahl (2004) found these equations to have the lowest uncertainty among a large number of equa- 
Table 1. Moraine parameter values used in the breaching equations.

\begin{tabular}{lrrrr}
\hline \multirow{2}{*}{ Parameter } & \multicolumn{4}{c}{ Scenario } \\
\cline { 2 - 6 } & Current conditions & \multicolumn{3}{c}{ Lake lowering } \\
\cline { 2 - 6 } & & 35 & $10 \mathrm{~m}$ & $20 \mathrm{~m}$ \\
\hline Moraine height $\left(h_{\mathrm{d}}, \mathrm{m}\right)$ & 35 & 32 & 25 & 15 \\
Breach height $\left(h_{\mathrm{b}}, \mathrm{m}\right)$ & 35 & 32 & 25 & 15 \\
Water height $\left(h_{\mathrm{w}}, \mathrm{m}\right)$ & 33.5 & 29.5 & 22.4 & 12.5 \\
Water volume above & & & & \\
breach invert $\left(V_{\mathrm{w}}, \mathrm{million} \mathrm{m}^{3}\right)$ & & & & \\
\end{tabular}

tions studied. Froehlich's equations (Froehlich, 1995) were used to predict breach width $(B, \mathrm{~m})$, failure time $\left(t_{\mathrm{f}}, \mathrm{h}\right)$ and peak discharge $\left(Q_{\mathrm{p}}, \mathrm{m}^{3} \mathrm{~s}^{-1}\right)$ are

$$
\begin{gathered}
B=0.1803 k V_{\mathrm{w}}^{0.32} h_{\mathrm{b}}^{0.19} \\
t_{\mathrm{f}}=0.00254 V_{\mathrm{w}}^{0.53} h_{\mathrm{b}}^{-0.9} \\
Q_{\mathrm{p}}=0.607 V_{\mathrm{w}}^{0.295} h_{\mathrm{w}}^{1.24}
\end{gathered}
$$

where the moraine parameters in these equations are the breach height $\left(h_{\mathrm{b}}, \mathrm{m}\right)$, the drainable water volume $\left(V_{\mathrm{w}}, \mathrm{m}^{3}\right)$, the depth of water above the breach invert at the time of failure $\left(h_{\mathrm{w}}, \mathrm{m}\right)$ and overtopping multiplier $k(k=1$ for no overtopping, and $k=1.4$ for overtopping). The values of these parameters are shown in Table 1 . The value of $V_{\mathrm{w}}$ in Table 1 was taken from the 2012 bathymetric survey results of Somos-Valenzuela et al. (2014). From a large database of dam breach cases, Wahl (2004) derived equations to calculate upper $\left(P_{\mathrm{u}}\right)$ and lower $\left(P_{1}\right)$ bounds for the breach parameters

$$
\left\{P_{1}, P_{\mathrm{u}}\right\}=\left\{P_{\mathrm{p}} \cdot 10^{-e-2 \mathrm{Se}}, P_{\mathrm{p}} \cdot 10^{-\bar{e}+2 \mathrm{Se}}\right\},
$$

where $P_{\mathrm{p}}$ is the predicted breach parameter value $\left(B, t_{\mathrm{f}}\right.$, or $Q_{\mathrm{p}}$ ) estimated by Eqs. (1)-(3), $e$ and 2 Se are the mean prediction error and the uncertainty band, respectively (Wahl, 2004) (see Table 2).

Froehlich's equations provide estimates of the breaching parameters, but to simulate the downstream inundation, the full hydrograph of the breaching event is needed. To obtain full breach hydrographs (lower, predicted and upper), we use the HEC-RAS dam break model (USACE, 2010) with the breach width $(B)$ and failure time $\left(t_{\mathrm{f}}\right)$ calculated from Eqs. (1)-(2). These hydrographs were adjusted to match the peak discharge $\left(Q_{\mathrm{p}}\right)$ values estimated from Eq. (3).

\subsection{Inundation model}

FLO-2D is used to calculate the flooding downstream of Imja Tsho due to a potential GLOF with the breaching hydrograph discussed in the previous section. The model is suitable to simulate the propagation of the debris flow (FLO2D, 2012), since the effects of sediments and debris have been shown to be very important factors in GLOF events (Osti and Egashira, 2009). Although the geometry of the grid within FLO-2D is two dimensional, the flow is modeled in eight directions and the model solves the one-dimensional Saint Venant equation independently in each direction. The continuity and momentum equations are solved with a central, finite difference method using an explicit time-stepping scheme. The total friction slope can be expressed as (O'Brien et al., 1993; Julien, 2010; FLO-2D, 2012)

$S_{\mathrm{f}}=S_{\mathrm{y}}+S_{\mathrm{v}}+S_{\mathrm{td}}=\frac{\tau_{\mathrm{y}}}{\gamma_{\mathrm{m}} h}+\frac{K \eta \omega}{8 \gamma_{\mathrm{m}} h^{2}}+\frac{n^{2} V^{2}}{h^{4 / 3}}$,

where $S_{\mathrm{y}}$ is the yield slope, $S_{\mathrm{v}}$ is the viscous slope, $S_{\mathrm{td}}$ is the turbulent-dispersive slope, $\tau_{\mathrm{y}}$ is the Mohr-Coulomb yield stress, $\gamma_{\mathrm{m}}$ is the specific weight of the sediment mixture, $K$ is a resistance parameter, $\eta$ is the Bingham dynamic viscosity, $V$ is the depth-averaged velocity and $n$ is the Manning roughness coefficient. Rheological properties, $\eta$ and $\tau_{\gamma}$, are formulated as exponential functions of the sediment volume concentration $c_{\mathrm{V}}$ (Julien and Leon, 2000; Julien, 2010)

$\eta=\alpha_{2} \mathrm{e}^{\beta_{2} c_{\mathrm{v}}}$

$\tau_{\gamma}=\alpha_{1} e^{\beta_{1} c_{\mathrm{v}}}$

where $\alpha_{i}$ and $\beta_{i}$ are empirical coefficients defined by laboratory experiment (FLO-2D, 2009). Since we have very limited geological information for the study area, the values recommended by the FLO-2D manual for $\alpha_{i}$ and $\beta_{i}$ are used $\left(\alpha_{1}=0.0765, \beta_{1}=16.9, \alpha_{2}=0.0648\right.$ and $\left.\beta_{2}=6.2\right)$. Rickenmann (1999) and Julien and Leon (2000) recommend using a concentration of $50 \%$ as an upper limit for debris flows when no other information is available.

\section{Results}

The Imja GLOF model described above was used to model four scenarios of a GLOF occurring from Imja Tsho: current lake conditions with the water surface at $5010 \mathrm{~m}$, and three flood mitigation scenarios with the lake water level lowered 3,10 and $20 \mathrm{~m}$. The flood mitigation scenarios represent possible lake lowering efforts starting with the current UNDP project to lower the lake at least $3 \mathrm{~m}$. In case this scenario does not provide any significant flood reduction downstream at Dingboche, the other scenarios can provide some guidance as to how much more the lake might need to be lowered to achieve reduced risk. It is important to note that no other studies have analyzed the potential benefits of lowering Imja Tsho, and the selection of a preferred lake lowering alternative needs to be based on such an analysis as that presented here.

\subsection{Moraine breaching model}

\subsubsection{Breach parameters}

Table 3 shows the results of using Eqs. (1)-(3) and the moraine characteristics in Table 1 to calculate the lower 
Table 2. Prediction error and uncertainty bands for the Froehlich breaching equations.

\begin{tabular}{lrr}
\hline & $\begin{array}{r}\text { Mean } \\
\text { prediction } \\
\text { error }(e)\end{array}$ & $\begin{array}{r}\text { Uncertainty } \\
\text { band }( \pm 2 \mathrm{Se})\end{array}$ \\
\hline Parameter & 0.01 & \pm 0.39 \\
Failure time $\left(t_{\mathrm{f}}, \mathrm{h}\right)$ & -0.22 & \pm 0.64 \\
Peak discharge $\left(Q_{\mathrm{p}}, \mathrm{m}^{3} \mathrm{~s}^{-1}\right)$ & -0.04 & \pm 0.32 \\
\hline
\end{tabular}

bound, predicted and upper bound values of the breaching parameters $\left(B, t_{\mathrm{f}}\right.$, and $\left.Q_{\mathrm{p}}\right)$. The upper and lower bounds of the breaching parameters were calculated from Eqs. (4)-(5) using the prediction errors and uncertainty bands from Table 2 . Lowering the lake level by $3 \mathrm{~m}$ does not result in a significant change in the failure time and only a $13.8 \%$ decrease in the peak discharge. However, lowering the level by $10 \mathrm{~m}$ has a major impact on peak discharge, reducing it by $58.5 \%$ and further lowering of the level to $20 \mathrm{~m}$ reduces the discharge by $73.8 \%$.

\subsubsection{Breach hydrographs}

Discharge hydrographs for potential moraine breaches at Imja Tsho were computed using the HEC-RAS dam break module and the lower bound, predicted and upper bound breach parameters under the current conditions scenario (see Table 4). The HEC-RAS hydrograph peak discharges were matched to the peak discharge values in Table 3 by adjusting the failure time within the range shown in the table. The predicted peak discharge is $8394 \mathrm{~m}^{3} \mathrm{~s}^{-1}$ (see Table $4-$ Imja Tsho) compared to $8274 \mathrm{~m}^{3} \mathrm{~s}^{-1}$ computed with Froehlich's equation, a difference of $1.4 \%$. The range of peak discharge (upper minus lower bound) is $14728 \mathrm{~m}^{3} \mathrm{~s}^{-1}$ compared to $14613 \mathrm{~m}^{3} \mathrm{~s}^{-1}$ computed by Froehlich's equation, about $0.8 \%$ difference. These results indicate good agreement between the HEC-RAS computed hydrograph values and the empirical Froehlich equation values.

\subsection{Inundation model}

The FLO-2D inundation model was used to compute the results of the four potential Imja Tsho GLOF scenarios. The first scenario considers the lake in its current condition with the lake level at $5010 \mathrm{~m}$ above mean sea level. Then alternatives with lake levels 3,10 , and $20 \mathrm{~m}$ lower than this were considered.

\subsubsection{Current conditions scenario}

The results (lower bound, expected value, upper bound) of modeling a potential GLOF from Imja Tsho under current conditions are shown in Table 4 and Figs. 4-6 at Dingboche (at the cross section indicated in Fig. 4). Table 4 also shows

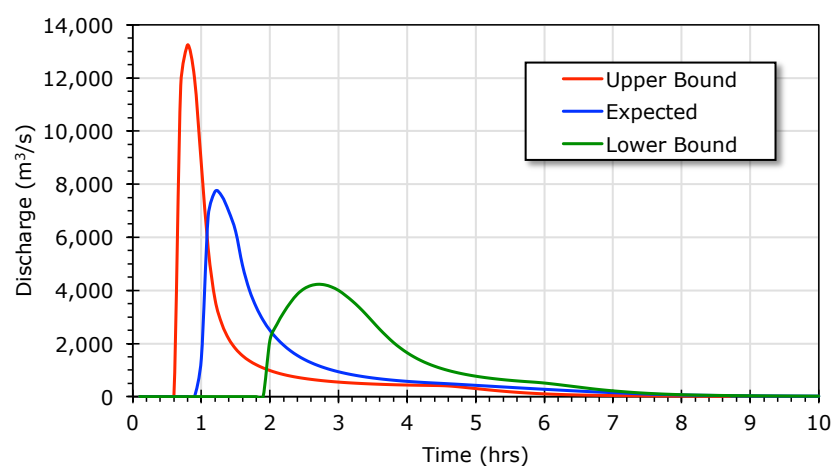

Figure 4. Upper bound, expected and lower bound GLOF hydrograph at Dingboche (cross section shown in Fig. 4) under current lake conditions.

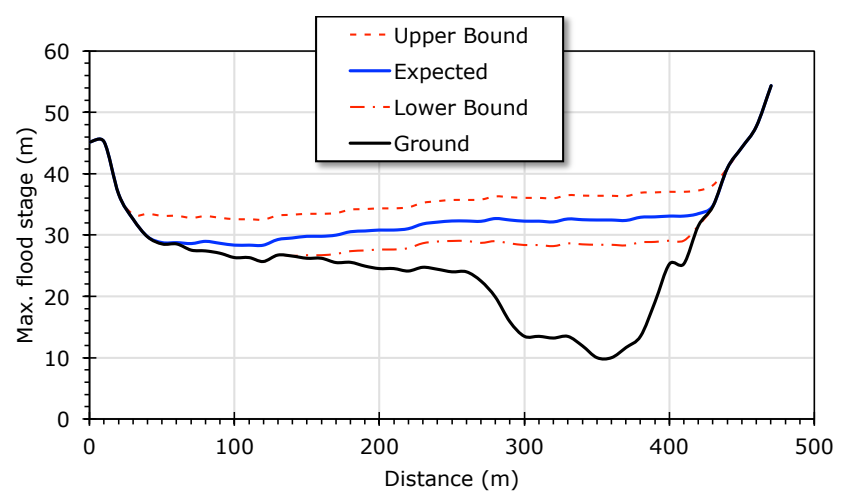

Figure 5. Upper bound, expected and lower bound GLOF flood stage at Dingboche (cross section shown in Fig. 4) under current conditions.

the flood arrival time, peak time, peak stage and flood peak discharge just downstream of Imja Tsho and at Dingboche. Fig. 4 shows the expected GLOF discharge hydrograph and bounds at Dingboche. The flood arrives at Dingboche $1 \mathrm{~h}$ after the breaching begins (range $0.6-1.9 \mathrm{~h}$ ), peaks at $1.3 \mathrm{~h}$ (range $0.8-2.8 \mathrm{~h}$ ) and is over after about $7 \mathrm{~h}$. Figure 5 shows the flood stage at Dingboche (upper bound, expected value, lower bound). The highest expected flood stage is $22.4 \mathrm{~m}$ (range 18.4-26.4 m) and the peak flow is $7544 \mathrm{~m}^{3} \mathrm{~s}^{-1}$ (range $4208-13248 \mathrm{~m}^{3} \mathrm{~s}^{-1}$ ). Figure 6 a shows the expected inundation at Dingboche. The lower and upper bounds are also shown in Fig. $6 \mathrm{~b}$ and $\mathrm{c}$, respectively.

The inundated area at Dingboche was mapped in Geographic Information System (GIS) and shows that, under the expected value simulation, most of the inundation is in the farming terrace areas and not the main lodges and other infrastructure along the primary trekking trail through the village (see Fig. 6a). With no lake lowering, about 9.4 ha of farmland will be inundated and 29 structures impacted (see Table 5, $0 \mathrm{~m}$ lowering scenario).

Further downstream at Phakding, the flooding also has an impact on potential flooding. At Phakding, the flood ar- 
Table 3. Breach parameter expected values and uncertainty bands for four scenarios.

\begin{tabular}{|c|c|c|c|c|}
\hline \multirow[b]{2}{*}{ Scenario } & \multirow{2}{*}{$\begin{array}{l}\text { Value } \\
\text { type }\end{array}$} & Breach width & Failure time & Peak discharge \\
\hline & & $B \quad(\mathrm{~m})$ & $t_{\mathrm{f}} \quad(\mathrm{h})$ & $Q_{\mathrm{p}} \quad\left(\mathrm{m}^{3} \mathrm{~s}^{-1}\right)$ \\
\hline \multirow{3}{*}{ Current conditions } & lower bound & 36 & 0.38 & 4342 \\
\hline & predicted & 91 & 1.01 & 8274 \\
\hline & upper bound & 218 & 7.32 & 18955 \\
\hline \multirow{3}{*}{ Lower 3 m } & lower bound & 34 & 0.39 & 3742 \\
\hline & predicted & 86 & 1.02 & 7131 \\
\hline & upper bound & 206 & 7.39 & 16336 \\
\hline \multirow{3}{*}{ Lower $10 \mathrm{~m}$} & lower bound & 30 & 0.42 & 2539 \\
\hline & nordicted & 75 & 11 & 4838 \\
\hline & upper bound & 180 & $\begin{array}{l}1.1 \\
7.97\end{array}$ & $\begin{array}{r}4050 \\
11083\end{array}$ \\
\hline \multirow{3}{*}{ Lower $20 \mathrm{~m}$} & lower bound & 22 & 0.49 & 1135 \\
\hline & predicted & 56 & 1.28 & 2163 \\
\hline & upper bound & 134 & 9.27 & 4955 \\
\hline
\end{tabular}

Table 4. Inundation model expected values and uncertainty bands at Imja Tsho, Dingboche and Phakding for current lake conditions.

\begin{tabular}{llrrrr}
\hline \multirow{2}{*}{ Station } & Value & $\begin{array}{r}\text { Arrival } \\
\text { time }(\mathrm{h})\end{array}$ & $\begin{array}{r}\text { Peak } \\
\text { time }(\mathrm{h})\end{array}$ & $\begin{array}{r}\text { Peak } \\
\text { discharge }\left(\mathrm{m}^{3} \mathrm{~s}^{-1}\right)\end{array}$ & $\begin{array}{r}\text { Peak } \\
\text { stage }(\mathrm{m})\end{array}$ \\
\hline Below Imja Tsho & lower bound & 0.8 & 2.3 & 4272 & 12.1 \\
& predicted & 0.3 & 1.0 & 8394 & 16.6 \\
& upper bound & 0.2 & 0.5 & 19000 & 33.4 \\
\hline \multirow{2}{*}{ Dingboche } & lower bound & 1.9 & 2.8 & 4208 & 18.4 \\
& predicted & 1.0 & 1.3 & 7544 & 22.4 \\
& upper bound & 0.6 & 0.8 & 3248 & 26.4 \\
\hline \multirow{3}{*}{ Phakding } & lower & 4.4 & 4.7 & 3412 & \\
& predicted & 3.1 & 3.2 & 3473 & \\
\hline
\end{tabular}

rives $3.1 \mathrm{~h}$ (range $2.4-4.4 \mathrm{~h}$ ) after the breaching begins and peaks at $3.2 \mathrm{~h}$ (range $2.6-4.7 \mathrm{~h}$ ) with a peak discharge of $3412 \mathrm{~m}^{3} \mathrm{~s}^{-1}$ (range $3171-3473 \mathrm{~m}^{3} \mathrm{~s}^{-1}$ ) (see Fig. 7). The lag time between the peak flow at Imja Tsho and the peak at Phakding is $2.2 \mathrm{~h}$ (see Table 4).

\subsubsection{Lake lowering scenarios}

A proposal to reduce the risk of a GLOF from Imja Tsho that is currently (2014) under implementation is to lower the water level of the lake at least $3 \mathrm{~m}$ (UNDP, 2013). The Imja GLOF model was used to assess the potential flood reduction at Dingboche if such a plan were to be implemented. To this end, the model was run with lake levels 3, 10 and $20 \mathrm{~m}$ lower than the current conditions scenario level $(5010 \mathrm{~m})$. The results for these scenarios are shown in Table 5 and Figs. 8-10. Figures 8 and 9 show the hydrographs and flood stage, respectively, at Dingboche for the 0,3,10 and $20 \mathrm{~m}$ lake lowering scenarios. Figure 10 maps the inundation depth at Dingboche for the different lake lowering scenarios. Lowering the lake $3 \mathrm{~m}$ (Fig. 10a) results in a $2.7 \%$ reduction in the peak flood depth at Dingboche (compared to the $0 \mathrm{~m}$ lowering scenario) with the peak flood height lowering $0.6 \mathrm{~m}$ (from 22.4 to $21.8 \mathrm{~m}$ ). This flood height still leads to significant inundation of homes and farmlands. With the lake lowered by $3 \mathrm{~m}$ about 8.6 ha of farmland and 25 structures are impacted by the flooding. In contrast, lowering the lake $10 \mathrm{~m}$ (Fig. 10b) or $20 \mathrm{~m}$ (Fig. 10c) results in a 14 and $36 \%$ flood height reduc- 
Table 5. Inundation model results at Dingboche and Phakding for lake lowering scenarios under current conditions.

\begin{tabular}{|c|c|c|c|c|c|c|c|c|}
\hline $\begin{array}{l}\text { Lake lowering } \\
\text { scenario } \quad(\mathrm{m})\end{array}$ & $\begin{array}{l}\text { Arrival } \\
\text { time (h) }\end{array}$ & $\begin{array}{r}\text { Peak } \\
\text { time (h) }\end{array}$ & $\begin{array}{l}\text { Peak discharge } \\
\qquad\left(\mathrm{m}^{3} \mathrm{~s}^{-1}\right)\end{array}$ & $\begin{array}{l}\text { Peak discharge } \\
\text { reduction* }(\%)\end{array}$ & $\begin{array}{r}\text { Peak } \\
\text { depth (m) }\end{array}$ & $\begin{array}{r}\text { Peak depth } \\
\text { reduction* }(\%)\end{array}$ & $\begin{array}{r}\text { Farm area } \\
\text { inundated }\left(\mathrm{m}^{2}\right)\end{array}$ & $\begin{array}{r}\text { Buildings } \\
\text { inundated (\#) }\end{array}$ \\
\hline \multicolumn{9}{|c|}{ Dingboche } \\
\hline 0 & 1.0 & 1.3 & 7544 & 0 & 22.4 & 0 & 93650 & 29 \\
\hline 3 & 1.1 & 1.5 & 7053 & 6.5 & 21.8 & 2.7 & 86262 & 25 \\
\hline 10 & 1.3 & 1.6 & 4479 & 40.6 & 19.2 & 14.3 & 40226 & 18 \\
\hline 20 & 1.3 & 1.8 & 1975 & 73.8 & 14.4 & 35.9 & 10686 & 0 \\
\hline \multicolumn{9}{|c|}{ Phakding } \\
\hline $0 \mathrm{~m}$ & 3.1 & 3.2 & 3412 & 0 & & & & \\
\hline $3 \mathrm{~m}$ & 3.2 & 3.5 & 2937 & 13.9 & & & & \\
\hline $10 \mathrm{~m}$ & 3.9 & 4.2 & 1730 & 49.3 & & & & \\
\hline $20 \mathrm{~m}$ & 5.8 & 6.1 & 629 & 81.8 & & & & \\
\hline
\end{tabular}

* Relative to the peak value for $0 \mathrm{~m}$ lake lowering.

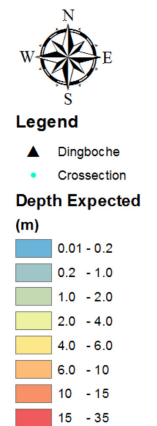

(a)

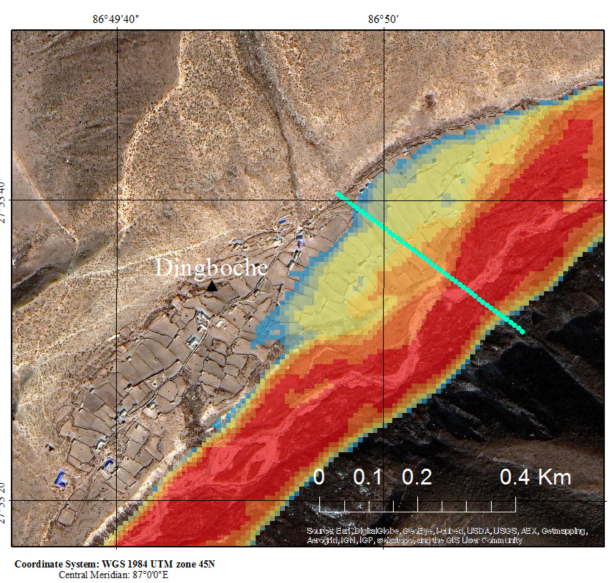

(b)
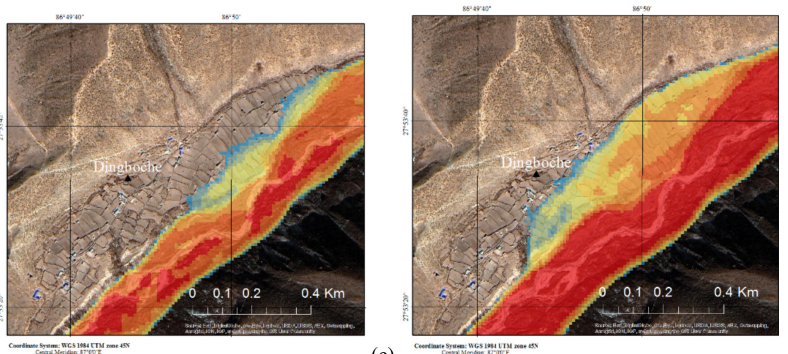

(c)

Figure 6. Inundation at Dingboche under current lake conditions: (a) expected inundation and the location of the cross section where the different scenarios are compared, (b) lower bound and (c) upper bound of the possible inundation.

tion, respectively, at Dingboche, with respective peak flood heights of 19.2 and $14.4 \mathrm{~m}$. These scenarios lead to considerable reduction in inundated area, especially the $20 \mathrm{~m}$ lowering scenario where the flood stays mostly in the historic flood plain of the river, inundates little farmland and floods no structures. When the lake is lowered $10 \mathrm{~m}$ about 4 ha of

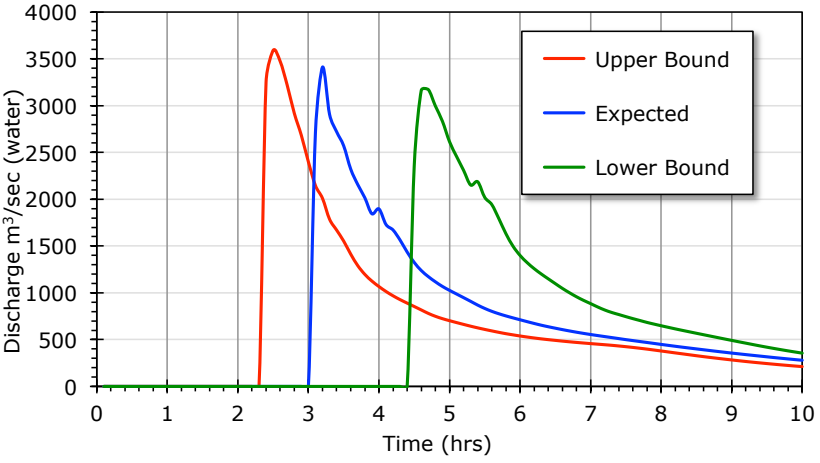

Figure 7. Upper bound, expected and lower bound GLOF hydrograph under current conditions at Phakding.

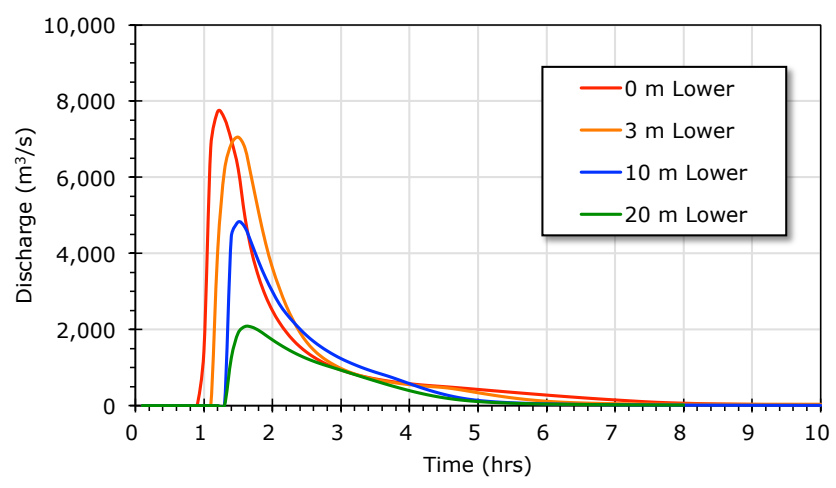

Figure 8. GLOF hydrographs at Dingboche under current lake conditions for $0,3,10$ and $20 \mathrm{~m}$ lake lowering scenarios.

farmland will be inundated and 18 structures impacted and at $20 \mathrm{~m}$ lowering about 1 ha of farmland will be inundated and 0 structures impacted. Additionally, the peak discharge is reduced by $6.5,40.6$ and $73.8 \%$ as a result of lowering the lake by 3,10 or $20 \mathrm{~m}$, respectively (Table 5). 


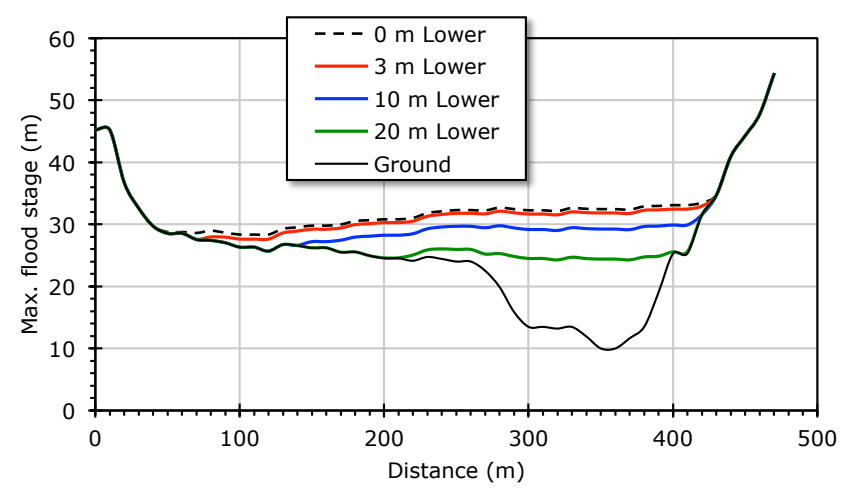

Figure 9. GLOF flood stage at Dingboche under current lake conditions for $0 \mathrm{~m}$ (expected), 3, 10 and $20 \mathrm{~m}$ lake lowering scenarios.

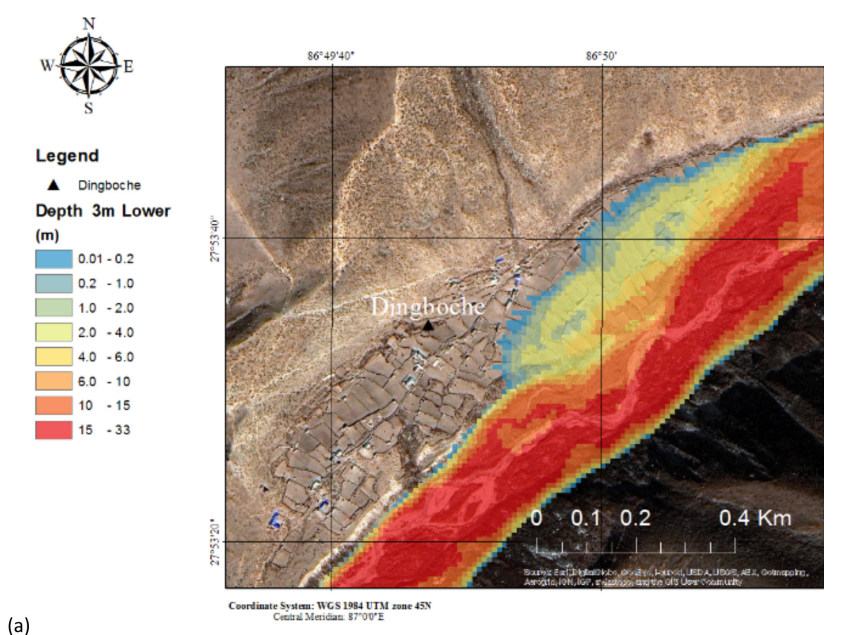

(a)

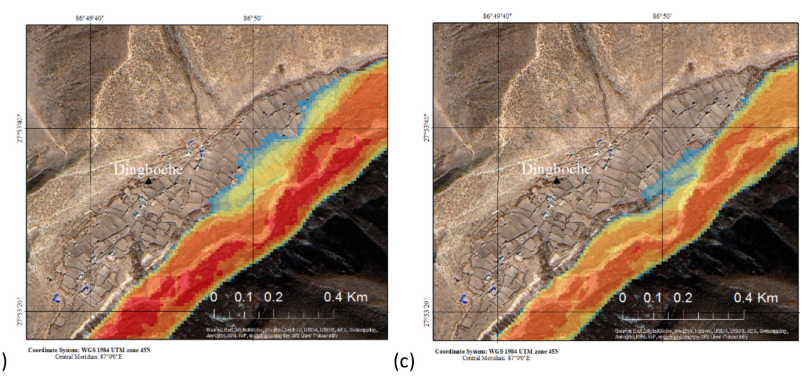

Figure 10. Inundation depth at Dingboche under current lake conditions: (a) $3 \mathrm{~m}$ lake lowering, (b) $10 \mathrm{~m}$ lake lowering and (c) $20 \mathrm{~m}$ lake lowering.

Further downstream at Phakding, the lake lowering scenarios have an impact on potential flooding as well (see Fig. 11). Lowering the lake $3 \mathrm{~m}$ results in a $13.9 \%$ reduction of peak flow at Phakding. In contrast, lowering the lake $10 \mathrm{~m}$ results in $49.3 \%$ reduction at Phakding, and lowering $20 \mathrm{~m}$ results in an $81.6 \%$ reduction at Phakding (see Table 5).

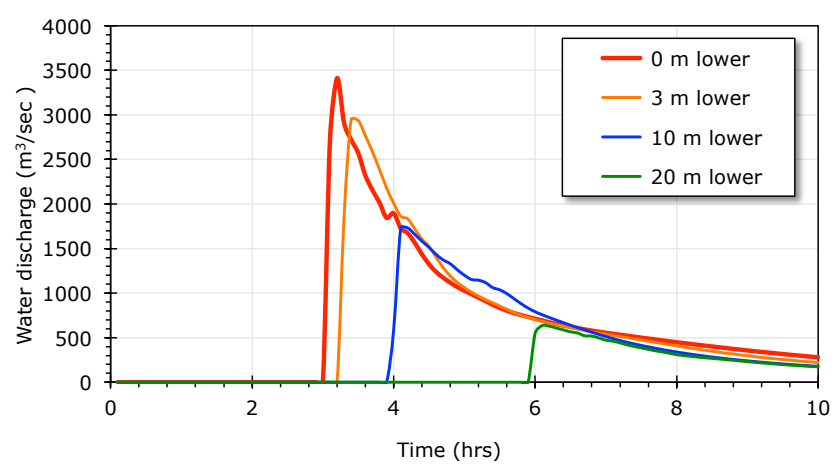

Figure 11. GLOF hydrographs at Phakding under current conditions for $0,3,10$ and $20 \mathrm{~m}$ lake lowering scenarios.

\section{Discussion}

\subsection{Comparison to previous Imja Tsho GLOF modeling}

HEC-RAS has been used to simulate GLOFs in the Nepal Himalaya by several other researchers. Cenderelli and Wohl (2001) used one-dimensional, steady-flow HEC-RAS modeling to estimate peak discharges of the 1977 Nare and 1985 Dig Tsho GLOFs. Osti and Egashira (2009) modeled the 1998 GLOF at Tam Pokhari using HEC-RAS to perform one-dimensional, unsteady-flow calculations; however, the model could not be used to model the debris flow. They note that the GLOF was very strong and damaging, and the peak discharge was much higher than the results of the wateronly computations. Other models have been used to model GLOFs. Dwivedi (2007) modeled the 1998 Tam Pokhari GLOF using the SOBEK flood model (Alkema and Middelkoop, 2005) and a $40 \mathrm{~m}$ resolution DEM. Several breaching scenarios were simulated, and eroded sediments were not considered in the model. Shrestha et al. (2013) modeled a potential debris-flow GLOF originating at Tsho Rolpa in the Rolwaling Valley of Nepal including the moraine breaching process due to an assumed seepage failure. Laboratory experiments were conducted to verify the model and good agreement with model results were obtained. Worni et al. (2012) who used the dynamic, erosion-based dam break model BASic EnvironMENT for simulation of environmental flow and natural hazard simulation (BASEMENT) (Faeh et al., 2011) to model a debris-flow GLOF in the Argentinian Patagonia. BASEMENT is a tool for the analysis of breaching processes of non-cohesive earthen dam structures and water-sediment flows (Volz et al., 2010). Schneider et al. (2014) simulated the cascade of mass movement processes of an avalanche triggered GLOF from Lake 513 in the Cordillera Blanca of Peru by coupling different physically based numerical models. Glacial lake dam overtopping hydrographs and water volumes were used as input for downstream debris-flow modeling with RAMMS (Christen et al., 2010). 
Bajracharya et al. (2007b) developed a water-flow GLOF model for Imja Tsho that simulated flood flow in the Imja Khola and Dudh Kosi from the lake to about $45 \mathrm{~km}$ downstream of the outlet near Phakding. That one-dimensional model used a DEM derived from satellite data $(30 \mathrm{~m} \times 30 \mathrm{~m}$ grid cells) and one interpolated from $40 \mathrm{~m}$ contour maps $(5 \mathrm{~m} \times 5 \mathrm{~m}$ grid cells). This is the same DEM that we used for the reach from Dingboche to Phakding. The bathymetry of Imja Tsho was taken from a 2002 survey indicating the total volume of the lake was $35.8 \pm 0.7$ million $^{3}$ (Sakai et al., 2007), rather than the $61.7 \pm 3.7$ million $^{3}$ total volume used in this study based on the more recent 2012 survey (Somos-Valenzuela et al., 2014). The US National Weather Service (NWS) BREACH model (Fread, 1988) was used to generate moraine breach hydrographs that were passed to a NWS Flood Wave model (FLDWAV) model (Fread and Lewis, 1998) and routed downstream. Peak flows at the cross sections of the FLDWAV model were input to a steadystate US Army Corps of Engineers HEC-RAS model (USACE, 2010) to predict inundation at key cross sections. ICIMOD (2011) extended the work of Bajracharya et al. (2007b) using additional field results to more accurately define the geotechnical parameters of the moraine. The lake bathymetry was updated from 2009 fieldwork with the total volume reported to be 35.5 million $\mathrm{m}^{3}$ (ICIMOD, 2011). The morainebreaching trigger was not specified and might be either overtopping or piping. The simulated breach depth was $30 \mathrm{~m}$, the same as we used here.

We can compare the results of ICIMOD (2011) with those reported here, since this is being asked of the consultants working on the UNDP Imja Tsho risk reduction project (UNDP, 2013). For the breaching process, ICIMOD reported a breaching time of $2.9 \mathrm{~h}$ with a peak discharge of $5817 \mathrm{~m}^{3} \mathrm{~s}^{-1}$, whereas we calculated $1.01 \mathrm{~h}$ (range 0.38 to $7.32 \mathrm{~h}$ ) and a peak of $8394 \mathrm{~m}^{3} \mathrm{~s}^{-1}$ (range 4272 to $19000 \mathrm{~m}^{3} \mathrm{~s}^{-1}$ ). At Dingboche, ICIMOD reported a flood arrival of $3.1 \mathrm{~h}$ with a peak of $3000 \mathrm{~m}^{3} \mathrm{~s}^{-1}$ (estimated from Fig. 8.2, p. 65), whereas we show flood arrival at $1 \mathrm{~h}$ (range $0.6-1.9 \mathrm{~h}$ ) and a peak of $7544 \mathrm{~m}^{3} \mathrm{~s}^{-1}$ (range 4208$13248 \mathrm{~m}^{3} \mathrm{~s}^{-1}$ ). At Ghat near Phakding, ICIMOD reported arrival at $4.2 \mathrm{~h}$ with a peak of $2300 \mathrm{~m}^{3} \mathrm{~s}^{-1}$, whereas we calculated $3.1 \mathrm{~h}$ (range $2.4-4.4 \mathrm{~h}$ ) with a peak of $3412 \mathrm{~m}^{3} \mathrm{~s}^{-1}$ (range $3171-3473 \mathrm{~m}^{3} \mathrm{~s}^{-1}$ ). The reason for the differences here is most likely the use of the significantly smaller Imja Tsho volume in the ICIMOD calculations due to the bathymetry used. This causes faster propagation of larger flows downstream. In assessing the possibly reduced risk to downstream communities from implementing a lake lowering alternative, it is recommended that the latest estimates of the volume and bathymetry of Imja Tsho be used, e.g., 2012 or later.

\subsection{Options for Imja Tsho risk reduction}

To date there is no agreed upon set of hazard indicators for Imja Tsho, or other potentially dangerous glacial lakes for that matter (Somos-Valenzuela et al., 2013); however, the definition of GLOF hazard from Imja Tsho was discussed in consultations with community members in Dingboche in September 2012 and subsequently. The hazard of an Imja Tsho GLOF did not exist 30 years ago (see SomosValenzuela et al. (2014) and Watanabe et al. (2009) for images showing the evolution of the lake), and the community members' vulnerabilities stem from the location of their homes and farms relative to the flood plain. For them, hazard is having their farms or homes flooded or washed away, a prospect that they want reduced and preferably eliminated (Somos-Valenzuela et al., 2013).

There are many impacts that might occur from a rapid uncontrolled GLOF from Imja Tsho that will be felt downstream, in particular there are several stretches of the main trekking trail from Namche Bazar to Lukla that run quite close to the river and would be washed away, as they were in the 1985 Dig Tsho GLOF (Ives, 1986; Vuichard and Zimmermann, 1986). In addition, some parts of villages along the trail have fields and houses near the river, and they may also be impacted. The feasibility of possible remedial actions at Imja Tsho to reduce the hazard to downstream communities was evaluated. One scenario that appears to have significant risk reduction possibility is the slow, controlled lowering of the lake by $20 \mathrm{~m}$. Lowering the lake by any amount will reduce the probability of GLOF occurrence for at least two reasons: the hydrostatic pressure on the west to east width of the moraine at the water level would be increased and more difficult to breach, and reducing the GLOF's occurrence probability would decrease the hazard level downstream.

Of the methods to reduce glacial lake risk, e.g., relocation of people and assets from the flood path, strengthening the lake outlet (Kattelmann and Watanabe, 1998), the one that has been employed the most is lowering the lake level. This has been used at nearly 40 dangerous glacial lakes in Peru since the 1950s (Portocarrero, 2014). Typically, the lake is lowered to a safe level by siphoning or draining and then excavating the damming moraine and installing a drainage channel at the desired elevation. Often, a reinforced earthen dam is then constructed to replace the original unconsolidated moraine dam, such that if a surge wave overtops the dam it will contain much of the excess water and not fail from erosion (Somos-Valenzuela et al., 2013). In order to lower glacial lakes, siphons are often used, e.g., at Hualcán Lake (Lake 513) in Peru (Portocarrero, 2014). Lowering glacial lakes more than about $5 \mathrm{~m}$ is infeasible at altitudes of $5000 \mathrm{~m}$, but greater lowering can be achieved using an incremental method as discussed below (Somos-Valenzuela et al., 2013).

The UNDP Imja Tsho project suggests that lowering the lake at least $3 \mathrm{~m}$ will achieve significant risk reduction downstream (UNDP, 2013), but there is no requirement to estimate 
the remaining risk when the lake is lowered to different levels $(3,10,20 \mathrm{~m})$. This work has attempted to analyze this question. Siphons may be used at Imja Tsho to progressively lower the level in $3-5 \mathrm{~m}$ increments followed by excavation of the lake outlet.

Previous studies have suggested deepening and strengthening the outlet of Imja Tsho (Maskey, 2012). However, there are many difficulties in implementing this method. First, the natural flow of the outlet must be interrupted somehow in order to perform any excavation of the channel. In the siphoning method discussed above, the lake is lowered and then the outlet can be excavated to that level without needing to divert the outlet flow. One method that has been proposed is to build a coffer dam and divert water to flow over another part of the damming moraine and then excavate the existing outlet channel of the lake to increase its depth and discharge (Maskey, 2012). The difficulties of employing this method include (1) possibly encountering ice during the excavation, significantly weakening the moraine and possibly inducing a GLOF; (2) diversion of the outlet flow might cause excessive erosion that could weaken the moraine and potentially lead to a GLOF; and (3) the existence of small ponds in the outlet complex that are separated with shallow necks (with as little as $1.5 \mathrm{~m}$ depth) through which the lake water flows might prevent the draining of the lake unless they were also excavated (Somos-Valenzuela et al., 2013). The difficulty of encountering buried ice exists in any method employing excavation of the damming moraine and the moraine must be examined in detail with geophysical methods before this can be done safely. The example of Tsho Rolpa is being used as a model lake lowering system for Imja Tsho (UNDP, 2013). An outlet channel was constructed at Tsho Rolpa and $3 \mathrm{~m}$ lowering was achieved; however, the design called for lowering the lake by $20 \mathrm{~m}$ which was never attempted because of funding limitations (Rana et al., 2000; Mool et al., 2001). Our results show that lowering Imja Tsho $3 \mathrm{~m}$ would not lead to a significant inundation reduction downstream. The lake should be lowered at least $10 \mathrm{~m}$ and probably $20 \mathrm{~m}$ to achieve significant hazard reduction. Lowering Imja Tsho will require draining: (1) the normal inflow to the lake, (2) the volume of the lake expansion during the time of drainage and (3) the volume of the lake necessary to achieve $3 \mathrm{~m}$ lowering per drainage cycle (Somos-Valenzuela et al., 2013). Lake discharge was measured in May 2012 by a group from Kathmandu University using a tracer dilution method (Maskey, 2012) and by the authors using a timed float method (SomosValenzuela et al., 2013). In both cases the flow was found to be approximately $1 \mathrm{~m}^{3} \mathrm{~s}^{-1}$.

The authors again measured the flow with a flow meter in September 2013 and found the discharge to be approximately $2 \mathrm{~m}^{3} \mathrm{~s}^{-1}$ (see above for description of method). The lake area was $1.257 \pm 0.104 \mathrm{~km}^{2}$ in September 2012, and increasing by about $0.04 \mathrm{~km}^{2} \mathrm{yr}^{-1}$. (Somos-Valenzuela et al., 2014). This will require $1.353 \mathrm{~m}^{3} \mathrm{~s}^{-1}$ of drainage to lower the lake $3 \mathrm{~m}$ during a 5 -month period in the melt season using 13 siphon pipes of $350 \mathrm{~mm}$ diameter.

\section{Conclusions}

Methods for reducing the downstream inundation hazard from a GLOF originating at Imja Tsho in Nepal were explored. A two-dimensional debris-flow model was developed to assess the downstream inundation. Inundation reducing scenarios were analyzed and an alternative under design, lowering the lake at least $3 \mathrm{~m}$, was found not to have significant flood reduction benefits. The results indicate that the lake needs to be lowered about $20 \mathrm{~m}$ in order to completely reduce the impacts that a GLOF could have at Dingboche and further downstream. The results show that a GLOF occurring under the current lake conditions would result in inundation of much of the farming areas (about 9.4 ha and 29 structures impacted) at Dingboche but not the main lodges and other infrastructure along the primary trekking trail through the village. Lowering lake $3 \mathrm{~m}$ does not change this result much, but $10 \mathrm{~m}$ lowering reduces the impact substantially with about 4 ha of farmland and 18 structures impacted, and at $20 \mathrm{~m}$ lowering almost all impact at Dingboche is prevented. All cases involving lowering the lake would require a coordinated sequence of siphoning to lower the water level in $3 \mathrm{~m}$ increments, followed by outlet excavation to maintain the new level. The process would be repeated as needed to reach the desired lake level.

Acknowledgements. The authors acknowledge the support of the USAID Climate Change Resilient Development (CCRD) project and the Fulbright Foundation for the support of Somos-Valenzuela. The support of the software developers of FLO-2D made much of the work reported here possible. The comments of T. Watanabe, $\mathrm{S}$. Bajracharya and an anonymous reviewer are greatly appreciated.

Edited by: M. Mikos

\section{References}

Alkema, D. and Middelkoop, H.: The Influence of Floodplain Compartmentalization on Flood Risk within the Rhine-Meuse Delta, Nat. Hazards, 36, 125-145, 2005.

Bajracharya, B. and Uddin, K.: Study of Land Cover Dynamics in Sagarmatha National Park and Buffer Zone, 10th Int. Symp. High Mt. Remote Sens. Cartogr. (Kathmandu, Nepal, 12-19 September 2008), 125-132, 2010.

Bajracharya, S. R., Mool, P. K., and Shrestha, B. R.: Impact of Climate Change on Himalayan Glaciers and Glacial Lakes Case Studies on GLOF and Associated Hazards in Nepal and Bhutan, International Centre for Integrated Mountain Development (ICIMOD), Kathmandu, 2007a.

Bajracharya, B., Shrestha, A. B., and Rajbhandari, L.: Glacial lake outburst floods in the Sagartmatha regions: hazard assessment 
using GIS and hydrological modeling, Mountain Res. Develop., 27, 336-344, 2007b.

Bolch, T., Buchroithner, M. F., Peters, J., Baessler, M., and Bajracharya, S.: Identification of glacier motion and potentially dangerous glacial lakes in the Mt. Everest region/Nepal using spaceborne imagery, Nat. Hazards Earth Syst. Sci., 8, 13291340, doi:10.5194/nhess-8-1329-2008, 2008.

Buchroithner, M. F., Jentsch, G., and Wanivenhaus, B.: Monitoring of recent geoligical events in the Khumbu Area (Himalaya, Nepal) by Digital Processing of Landsat MSS Data, Rock Mechan., 15, 181-197, 1982.

Cenderelli, D. A. and Wohl, E. E.: Peak discharge estimates of glacial-lake outburst floods and "normal" climatic floods in the Mount Everest region, Geomorphology, 40, 57-90, 2001.

Christen, M., Kowalski, J., and Bartelt, P.: RAMMS: numerical simulation of dense snow avalanches in three-dimensional terrain, Cold Reg. Sci. Technol., 63, 1-14, 2010.

Dwivedi, S. K.: Two Dimensional Simulation of a Glacial Lake Outburst Flood (A Case Study of Tam Pokhari Lake; Nepal Himalaya), MS Thesis, International Institute for Geo-information Science and Earth Observation, Enshede, The Netherlands, February, 2007.

Faeh, R., Mueller, R., Rousselot, P., Veprek, R., Vetsch, D., Volz, C., Vonwiller, L., and Farshi, D.: BASEMENT - Basic Simulation Environment for Computation of Environmental Flow and Natural Hazard Simulation, VAW, ETH Zurich, available at: http://www.basement.ethz.ch (last access: 13 February 2015), 2011

Flo-2D: Flo-2D User's Manual, FLO-2D Software, Inc., Nutrioso, AZ, 2009.

Flo-2D: Flo-2D Pro Reference Manual, FLO-2D Software, Inc., Nutrioso, AZ, 2012.

Fread, D. L.: BREACH, an Erosion Model for Earthen Dam Failures, United States National Weather Service, Hydrologic Research Laboratory, Silver Spring, Maryland, 58 pp., 1988.

Fread, D. L. and Lewis, J. M.: NWS FLDWAV Model, Theoretical Development, User Document, Silver Spring, MD, 1998.

Froehlich, D. C.: Embankment dam breach parameters revisited, Proc., 1st Int. Conf. on Water Resources Engineering, American Society of Civil Engineers, 14-18 August 1995, New York, 887-891, 1995.

Froehlich, D. C.: Embankment dam breaches and their uncertainties, J. Water Resour. Plann. Manage., 121, 90-97, 2008.

Fujita K., Sakai, A., Nuimura, T., Yamaguchi, S., and Sharma, R. R.: Recent changes in Imja Glacial Lake and its damming moraine in the Nepal Himalaya revealed by in-situ surveys and multi-temporal ASTER imagery, Environ. Res. Lett. 4, 045205, doi:10.1088/1748-9326/4/4/045205, 2009.

Fujita, K., Sakai, A., Takenaka, S., Nuimura, T., Surazakov, A. B., Sawagaki, T., and Yamanokuchi, T.: Potential flood volume of Himalayan glacial lakes, Nat. Hazards Earth Syst. Sci., 13, $1827-$ 1839, doi:10.5194/nhess-13-1827-2013, 2013.

Hambrey, M. J., Quincey, D. J., Glasser, N. F., Reynolds, J. M., Richardson, S. J., and Clemmens, S.: Sedimentological, geomorphological and dynamic context of debris-mantled glaciers, Mountain Everest (Sagarmatha) region, Nepal, Quaternary Sci. Rev., 27, 2361-2389, 2008.
Hammond, J. E.: Glacial lakes in the Khumbu region, Nepal: An assessment of the hazards, unpublished MA Thesis, University of Colorado, Boulder, CO, 1988.

ICIMOD-International Centre for Integrated Mountain Development: Glacial lakes and glacial lake outburst floods in Nepal, International Centre for Integrated Mountain Development (ICIMOD), Kathmandu, Nepal, 2011.

Ives, J.: Glacial Lake Outburst Floods and Risk Engineering in the Himalaya, International Centre for Integrated Mountain Development (ICIMOD) Occasional Paper No. 5, Kathmandu, Nepal, 1986.

Ives, J. D., Shrestha, R. B., and Mool, P. K.: Formation of glacial lakes in the Hindu Kush-Himalayas and GLOF risk assessment. International Centre for Integrated Mountain Development (ICIMOD), Kathmandu, Nepal, 2010.

Julien, P. Y.: Erosion and Sedimentation, 2nd Edn., Cambridge University Press, Cambridge, UK, 2010.

Julien, P. Y. and Leon, C. A.: Mud floods, mudlows and debris flows classification, rheology and structural design, Int. Work. Mudflows debris flows, 1-16, Caracas, Venezuela, 27 November-1 December, 2000.

Kattelmann, R.: Glacial Lake Outburst Floods in the Nepal Himalaya: A Manageable Hazard?, Nat. Hazards, 28, 145-154, 2003.

Kattelmann, R. and Watanabe, T.: Approaches to Reducing the Hazard of an Outburst Flood of Imja glacier Lake, Khumbu Himal. Proc. of International Conference on Ecohydrology of High Mountain Areas, Kathmandu, Nepal, 24-28 March 1996, 359366, UNESCO, 1998.

Lamsal, D., Sawagaki, T., and Watanabe, T.: Digital Terrain Modelling Using Corona and ALOS PRISM Data to Investigate the Distal Part of Imja glacier, Khumbu Himal, Nepal. J. Mt. Sci., 8, 390-402, 2011.

Maskey, R. K.: Topographic Survey and Engineering Design of the Outlet Channel and Pre-feasibility Study for a Mini-Hydropower Generation Facility from Imja Lake. USAID ADAPT AsiaPacific Support to UNDP/Nepal: Community Based GLOF and Flood Risk Reduction Project, United States Agency for International Development, Bangkok, 2012.

MoE-Ministry of the Environment: National Adaptation Programme of Action to Climate Change, Kathmandu, Nepal, 2010.

Mool, P. K., Bajracharya, S. R., and Joshi, S. P.: Risk Assessment of Lake Rolpa Glacial Lake along the Rolwaling and Tama Kosi Valleys Dolakha District, Nepal, International Centre for Integrated Mountain Development (ICIMOD), Kathmandu, Nepal, 2001.

O'Brien, J. S, Julien, P. Y., and Fullerton, W. T.: Two-Dimensional water Flood and mudlow simulation, J. Hydraul. Eng., 119, 244 261, 1993.

Osti, R. and Egashira, S.: Hydrodynamic characteristics of the Tam Pokhari Glacial Lake outburst flood in the Mt . Everest region, Nepal, Hydrol. Process., 23, 2943-2955, doi:10.1002/hyp.7405, 2009.

Portocarrero, C.: The Glacial Lake Handbook: Reducing Risk from Dangerous Glacial Lakes in the Cordillera Blanca, Peru, United States Agency for International Development, Washington, DC, 2014.

Rana, B., Shrestha, A. B., Reynolds, J. M., Aryal, R., Pokhrel, A. P., and Budhathoki, K. P.: Hazard Assessment of the Lake Rolpa 
Glacier Lake and Ongoing Remediation Measures, J. Nepal Geol. Soc., 22, 563-570, 2000.

Rickenmann, D.: Empirical Relationships for Debris Flows, Nat. Hazards, 19, 47-77, 1999.

Sakai, A., Saito, M., Nishimura, K., Yamada, T., Iizuka, Y., Harada, K., Kobayashi, S., Fujita, K., and Gurung, C. B.: Topographical survey of end-moraine and dead ice area at the Imja Glacial Lake in 2001 and 2002, B. Glaciol. Res., 24, 29-36, 2007.

Schneider, D., Huggel, C., Cochachin, A., Guillén, S., and García, J.: Mapping hazards from glacier lake outburst floods based on modelling of process cascades at Lake 513, Carhuaz, Peru, Adv. Geosci., 35, 145-155, doi:10.5194/adgeo-35-145-2014, 2014.

Shrestha, A. B. and Aryal, R.: Climate change in Nepal and its impact on Himalayan glaciers, Reg. Environ. Change, 11 (Suppl 1), S65-S77, 2011.

Shrestha, B. B, Nakagawa, H., Kawaike, K., Baba, Y., and Zhang, H.: Glacial hazards in the Rolwaling valley of Nepal and numerical approach to predict potential outburst flood from glacial lake, Landslides, 10, 299-313, doi:10.1007/s10346-012-0327-7, 2013.

Somos-Valenzuela, M., McKinney, D. C., Byers, A. C., Rounce, D. R., and Portocarrero, C.: Modeling Mitigation Strategies for Risk Reduction at Imja Lake, Nepal, High Mountain Glacial Watershed Program, CRWR Online Report 13-06, Center for Research in Water Resources, University of Texas at Austin, 2013

Somos-Valenzuela, M. A., McKinney, D. C., Rounce, D. R., and Byers, A. C.: Changes in Imja Tsho in the Mount Everest region of Nepal, The Cryosphere, 8, 1661-1671, doi:10.5194/tc-81661-2014, 2014.

Tachikawa, T., Hato, M., Kaku, M., and Iwasaki, A.: Characteristics of ASTER GDEM Version 2, Geoscience and Remote Sensing Symposium (IGARSS), Institute of Electrical and Electronics Engineers (IEEE), 3657-3660, 24-29 July, Vancouver, British Columbia, Canada, doi:10.1109/IGARSS.2011.6050017, 2011

UNDP-United Nations Development Programme: Community Based Glacier Lake Outburst and Flood Risk Reduction in Nepal. Project Document, UNDP Environmental Finance Services, Kathmandu, Nepal, 2013.
USACE-U.S.: Army Corps of Engineers: HEC-RAS River Analysis System Hydraulic Users Manual (Version 4.1), Hydrological Engineering Center, Davis, CA, 2010.

Volz, C., Rousselot, P., Vetsch, D., Mueller, R., Faeh, R., and Boes, R.: Numerical modeling of dam breaching processes due to overtopping flow. In: Proc. 8th ICOLD European Club Symposium 2010, 22-23 September, Innsbruck, Austria, 691-696. 2010.

Vuichard, D. and Zimmermann, M.: The Langmoche Flash-Flood, Khumbu Himal, Nepal, Mount. Res. Develop., 6, 90-94, 1986.

Wahl, T. L.: Uncertainty of Predictions for Embankment Dam breach Parameters, J. Hydraul. Eng., 130, 389-397, 2004.

Wahl, T. L.: Dam Breach Modeling-An Overview Of Analysis Methods, Joint Federal Interagency Conference on Sedimentation and Hydrologic Modeling, 27 June-1 July, Las Vegas, NV, 2010.

Watanabe, T., Kameyama, S., and Sato, T.: Imja glacier deadice melt rates and changes in a supra-glacial lake, 1989-1994, Khumbu Himal, Nepal: Danger of lake drainage, Mountain Res. Develop., 15, 293-300, 1995.

Watanabe T., Lamsal, D., and Ives, J. D.: Evaluating the growth characteristics of a glacial lake and its degree of danger of outburst flooding: Imja glacier, Khumbu Himal, Nepal, Norsk Geografisk Tidsskrift, 63, 255-267, 2009.

Westoby, M. J., Glasser, N. F., Brasington, J., Hambrey, M. J., Quincey, D. J., and Reynolds, J. M.: Modelling outburst floods from moraine-dammed glacial lakes, Earth Sci. Rev., 134, 137159, doi:10.1016/j.earscirev.2014.03.009, 2014.

WGMS-World Glacier Monitoring Service: Preliminary Glacier Mass Balance Data 2010/2011, available at: http://www.wgms. ch/mbb/sum11.html, last access: 17 January 2013.

Worni, R., Stoffel, M., Huggel C., Volz, C., Casteller, A., and Luckman, B.: Analysis and dynamic modeling of a moraine failure and glacier lake outburst flood at Ventisquero Negro, Patagonian Andes (Argentina), J. Hydrol., 444-445, 134-145, 2012. 